Journal of Southeast Asian

\title{
Transnational Vietnamese: Language Practices, New Literacies, and Redefinition of the "American Dream"
}

Nguyen Dao

University of Texas, San Antonio, nguyen.dao@utsa.edu

Follow this and additional works at: https://docs.lib.purdue.edu/jsaaea

Part of the Anthropological Linguistics and Sociolinguistics Commons, Applied Linguistics Commons, Discourse and Text Linguistics Commons, and the Language and Literacy Education Commons

\section{Recommended Citation}

Dao, Nguyen (2019) "Transnational Vietnamese: Language Practices, New Literacies, and Redefinition of the "American Dream"," Journal of Southeast Asian American Education and Advancement: Vol. 14 : Iss. 1, Article 4.

DOI: $10.7771 / 2153-8999.1175$

Available at: https://docs.lib.purdue.edu/jsaaea/vol14/iss1/4

This document has been made available through Purdue e-Pubs, a service of the Purdue University Libraries. Please contact epubs@purdue.edu for additional information.

This is an Open Access journal. This means that it uses a funding model that does not charge readers or their institutions for access. Readers may freely read, download, copy, distribute, print, search, or link to the full texts of articles. This journal is covered under the CC BY-NC-ND license. 
Transnational Vietnamese: Language Practices, New Literacies, and Redefinition of the "American Dream"

\section{Cover Page Footnote}

I hereby express my sincere gratitude to Phi's family, a total of four individuals who wholeheartedly participated in this study. Their extraordinary hospitality, support, knowledge, and lived experiences became the very foundation of my work. 


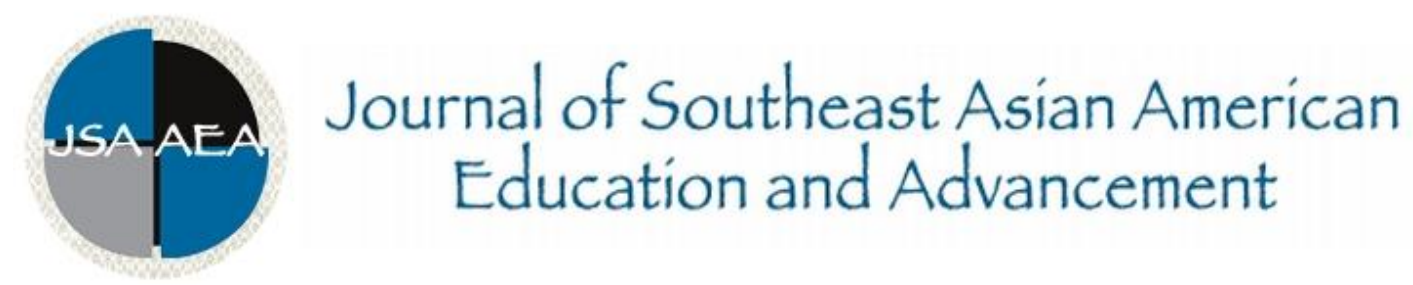

Vol. 14 Iss. 1 (2019)

WWW.JSAAEA.org

\title{
Transnational Vietnamese: Language Practices, New Literacies, and Redefinition of the "American Dream"
}

\author{
Nguyen Dao \\ University of Texas at San Antonio
}

\begin{abstract}
The research focuses on the transnational literacy and language practices of a Vietnamese immigrant family in Midwestern United States. Drawing upon multiple bodies of contemporary research and conceptual frameworks, this investigation intends to go beyond transnational movements to indicate the complex nature of bi-literate, bilingual and bi-cultural development and the role of national and supranational ideologies, as well as to describe how the Vietnamese diaspora have mobilized their identities and in so doing, redefined the provoking term "the American Dream."
\end{abstract}

Keywords: Transnationalism, migration, immigrant, language learning, sociolinguistics, literacy, identity, Vietnamese.

\footnotetext{
(C)

SDRERIIGHISRESERNEDR Readers are free to copy, display, and distribute this article, as long as the work is attributed to the author(s) and the Journal of Southeast Asian American Education \& Advancement, it is distributed for non-commercial purposes only, and no alteration or transformation is made in the work. More details of this Creative Commons license are available at http://creativecommons.org/licenses/by-nc-nd/3.0/. All other uses must be approved by the author(s) or JSAAEA. Journal of Southeast Asian American Education \& Advancement, Vol. 14. Iss. 1. (2019) ISSN: 2153-8999
} 


\section{Introduction}

This paper offers insights into complex issues of language and literacy practices in transnational Vietnamese communities in contexts of migration, as well as into how the migrants navigate and position themselves in various socio-cultural fields within and across national boundaries, thus aiming to demonstrate how cross-border practices have changed over the years among Vietnamese diasporic population from what I term the Old Enclave, or the original Vietnamese diaspora built upon anti-communism, to the New Enclave, or the recent Vietnamese diaspora built upon neoliberalism and new cosmopolitanism. ${ }^{1}$ Employing the theoretical framework of transnationalism, new literacies study, and identity, this research aims to shed light on the ways in which a Vietnamese migrant family has developed their transnational literacy and negotiated contradictory language ideologies and identities, thus successfully acculturating themselves into the mainstream society. The study is focused on addressing (a) the ways in which the first-generation Vietnamese immigrants trans-literacy worked, (b) their perceptions upon passing down their linguistic/cultural repertoire and literacy to their children, and (c) their redefinition of the "American Dream."

This paper is comprised of four parts: The literature review gives a brief yet comprehensive overview of the previous studies in recent years. The next part describes the methodological approach and how the research was conducted based upon available conceptual and methodological constructs. Through a detailed analysis of the noted narratives, the main body of the research sheds light on the participants' transnational literacy and language practices, the accompanying ideologies, and how their socio-cultural beliefs have transformed from the Old Enclave to the New Enclave. To give appropriate answers to the research questions above, this part also delves deeper into the narratives by discussing the gradual change in how the transnational Vietnamese immigrants renegotiate their identities and redefine the term "American Dream." To conclude the study, I recommend some suggestions for future directions, with regard to transnationalism placed within the contemporary, modern contexts.

\section{Literature Review}

This study involves a wide range of literature on new literacies research, language and identity studies, and transnational ideologies. In particular, Schiller, Basch, and Blanc-Szanton (1992) were able to address the complex, multi-dimensional nature of transnationalism, that is, social, cultural, economic capitals that transcend across national boundaries, along with the flow of migration (Duran, 2017). The notion of transnationalism then led to an emerging number of scholarly works in various fields, especially with regard to transnational literacies, language learning, and identities, for example, transmigrants' literacy and language practices while adapting to new contexts in the host country, how migrant communities maintain transnational affiliations with the home country, and how those practices reflect their shifting positions and reconstruction of identities (Apparudai, 1996; Basch, 1994; Duran, 2017; Norton, 2000; Smith, 2003; SuarezOrozco, 2001; Warriner, 2007). Furthermore, in recent years, the fields of literacy, language, and identity studies have transcended traditional pedagogical settings and psycholinguistic frameworks to adopt the post-structuralist approach, which means they have been studied within its embedded sociocultural contexts.

More specifically, the last decade has witnessed the advent of many works in New Literacies Studies. Street $(2003,2007)$ argues literacy has turned away from measurement of skills and is thus considered as social practices that vary from one context to another. Following this 
spirit, many literacy scholars have expanded the social lens of literacy practice to a broader term transnational literacy, whose notion consists of cross-border movements, language practices, new identity construction, technology, mobility, the relationship of local and global, and the complex dynamics of the current globalized world (Baynham \& Prinsloo, 2009; Block, 2010; Lam \& Warriner, 2012; Moje \& Luke, 2009; Norton, 2013; Street, 2007, 2009; Schneider, 2014).

When it comes to identity studies, Moje and Luke (2009) discuss how identities shape and are shaped by literacy practices and they suggest the approach of academic literacy as a way to empower one's identity. In a similar manner, Norton's studies $(2000,2013)$ point out how one's sense of self is negotiated in relation to a larger social world through investment in language learning, and how proficiency in powerful languages can grant access to greater symbolic and material resources, thereby empowering and reconstructing one's identity. Following the identity approach to literacy and language development, there has been a strong methodological focus on narratives from many scholars (Barkhuizen, 2008; Block, 2006; Early \& Norton, 2012; Miller, 2003). This methodological focus may bring about a critical research paradigm, in which it foregrounds an individual's sense over meaning-making of their experience as well as the complexity of individual-social relationships (Norton, 2013).

Bringing refreshed perspectives to literacy studies, Black (2008) further discusses the notion of the third space, or new forms of technological communication and media, which promotes multimodal development literacy and identity. Norton \& Darvin (2014) too regard technology as a powerful tool for migrant learners to maintain connections with their homeland as well as to establish new ways of learning, thus re-negotiating their transnational literacies and identities. Also, in the last decade, there has been an emerging body of scholarly works that investigate and document the new roles of transnational media and technology among migrant families (Benitez, 2006; Cruickshank, 2006; Panagakos \& Horst, 2006; Sanchez \& Salazar, 2012; Wilding, 2006).

Lam and Warriner (2012) shed a new light on transnationalism and literacy by addressing various studies on trans-literacy, which reflects upon how transnational affiliations influence literacy and language practices at multiple scale levels among different immigrant families in the United States. They also give directions and pedagogical implications for new literacy studies in modern transnational contexts. In the same vein, several migration, sociolinguistics, and literacy scholars have conducted research on how national and supranational ideologies have an influence on immigrants' cross-border practices, linguistic ideologies, and identities (El-Haj, 2007; Rubinstein-Avila, 2007; Schneider, 2014).

Taking those studies of transnationalism to a narrower and more relevant scope, in her longitudinal study on the phonological acquisition of English of a Vietnamese immigrant family, Hansen (2006) offers insights into L2 developmental processes as well as the constraints in acquiring a non-native linguistic system, embedded within social factors such as daily language practices, language ideologies, identity formation, and gender. Lam's autobiography (2005) describes how American narratives reshaped his lived experiences and points of view on the world, leading him towards individualism and new cosmopolitanism - in which nationalism is embedded within transnationalism and cultural pluralism. Following this spirit, Thuy (2005) and Lieu (2011) provide an in-depth investigation into Vietnamese immigrant communities' trans-border practices, concerning how cultural productions of entertainment and arts help reconstruct Vietnamese diaspora's cultures, identities, and definition of the American Dream.

While the majority of scholarly works that involve Vietnamese-Americans have mainly discussed their reconstruction of identities, cultural preservation, and language acquisition 
constraints across the ethnic enclaves, only few studies have delved into other cross-border practices taking place in smaller, informal settings, e.g. individual households, privately-held businesses, community centers, etc. Therefore, under the paradigms of transnationalism, New Literacies, and identity studies, this paper intends to go beyond transnational movements to illuminate the complex nature of bi-literate, bilingual and bicultural development and the role of translocal and supranational ideologies in such process, as well as to describe how the Vietnamese diaspora have reconstructed their identities and redefined the provoking notion "American Dream."

\section{Methodology}

Necessarily, this study concentrates on how trans-literacy and language practices implement themselves upon immigrants and how this is connected to their larger engagement in varied social discourses. Therefore, to go beyond in-depth descriptions and interpret meanings behind them, I chose to adopt the approach of ethnographic case study for the research. Apart from a thick description (Geertz, 1973), the ethnographic method grants an extensive access to cultural structures and contexts, as well as the insiders' views on a particular culture in order to gain deeper insights into different situated behaviors and ideologies, whether perceived or imagined (Geertz, 1973; Gobo, 2008; Rubinstein-Avila, 2007; Schneider, 2014). Ethnography also allows the inclusion of the insiders' voices, thereby offering an emic perspective rather than an etic one (Blommaert, 2005). Furthermore, the ethnographic approach is representative of the post-modern and post-structuralist turn in qualitative research, which links narratives with multiple dynamic social constructs.

The participants included Phi, a middle-aged Vietnamese woman who currently resides in Wichita, Kansas, along with her husband, Binh, and two sons, Nhan and Van (see Table 1). The first reason I chose Phi and her family as participants is that I speculated that their narratives would play a significant role in this study because they relocated from San Jose (the Old Enclave) to Wichita (the New Enclave) five years ago; hence, her experiences would not only encompass different ideologies and trans-border literacy and language practices in both the Old Enclave and the New Enclave but also indicate how they have progressed across time and space. Last but not least, through Phi, I would like to shed light on the complications concerning trans-local aspects (relocation within the United States) placed within transnationalism (migration from Vietnam to the United States).

Table 1. Demographic information of the participants.

\begin{tabular}{llcr}
\hline Name $^{2}$ & Gender & Age & Linguistic Repertoires \\
\hline Phi & Female & 46 & Vietnamese Native \\
Binh & Male & 58 & English Upper Intermediate \\
& & & Vietnamese Native \\
English Beginner \\
Nhan & Male & 17 & Bilingual Vietnamese-English \\
Van & Male & 14 & Bilingual Vietnamese-English \\
\hline
\end{tabular}

To attain the emic perspective, for three weeks in June 2017, I actively became a part of the participants' world, or a "quasi-member" (Schneider, 2014, p. 7) of the family, or the target 
community, to gain insights into the participant family's transnational lived experiences. In so doing, I took multiple roles at the site: a quasi-family member, a friend, and a researcher. Since a young age, I had built a long-term and close rapport with Phi's family; therefore, I gained their trust and recognition as one of the family members during the course of my stay. Being a quasifamily member enabled me to learn about the participants' daily activities in the natural setting through directly participating in those activities, which served as a major advantage with regard to obtaining access to the participants' world and rich ethnographic data.

To collect the data, I drew upon observation field notes, noted narratives, face-to-face, oneon-one informal conversations and open-ended interviews that aimed to examine the participants' social contexts, transnational lives, adaptation, trans-literacy, language practices, and new perspectives on their resettlement. The obtained data were analyzed intensively, holistically, and continuously, driven by qualitative case studies (Merriam, 1998) and grounded theory (Charmaz, 2006). The interview data, in particular, were analyzed employing three sets of coding: open coding, focused coding, and context coding (Corbin \& Strauss, 2008). The data reported were necessarily selective and partial, including quotes and reflections from the participant. With the purpose of establishing more authenticity, all the original transcriptions in Vietnamese are translated verbatim into English in this paper.

Also inspired by several post-modern identity researchers who adopt post-structuralist theory (Block, 2006; Moje \& Luke, 2009; Norton, 2013; Schneider, 2014), I broke down the data utilizing discourse analysis to the selected excerpts and narratives, with the intent to illuminate the ways in which the migrant participants' language learning, literacy practices, and identities have been shaped and reshaped over time through various socially-situated activities and practices. Also, according to Schneider (2014), discourse, along with its attribution to deconstructing and reshaping one's social world, is one of the fundamental theoretical frameworks of studying transnational ideologies among diasporic communities.

\section{Data Analysis and Interpretation}

\section{Background}

On April 30 ${ }^{\text {th }}$, 1975, Saigon, the capital city of South Vietnamese Government, fell to North Vietnamese communist forces. The incident effectively marked the end of the Vietnam War. The Fall of Saigon brought about a large Vietnamese migration to the United States. Since 1975, there have been four major immigration waves: (a) Evacuees who left right after the defeat of Saigon on April 30, 1975, including military personnel, professionals, and intellectuals associated with the U.S. army and the Republic of South Vietnam; (b) boat people who escaped between 1976 and 1977, admitted into the United States through the Indochinese Parole Program; (c) boat people including Vietnamese of Chinese descent who fled between 1978 and 1982 under the 1980 Refugee Act; and (d) Amerasians and former political prisoners who left in the 1980s (Vo, 2000).

Phi's father-in-law was among the fourth wave of evacuated refugees in the 1980s. In 2006, Phi migrated to the United States reuniting with her father-in-law's family. Her brother had already moved to Wichita, Kansas along with his wife. (They later moved to Worcester, Boston). Phi's family originally settled in San Jose, California. However, after two years, the economic crisis of 2008 rendered Phi and her husband unable to find a stable job. From her brother, Phi was aware of more job opportunities in Wichita, where she decided to relocate and has resided there until today. 


\section{Transnational literacy and language practices}

Despite her expertise as a middle-school English teacher in Vietnam, Phi had difficulties adjusting to American English during the early years of her resettlement. According to Phi:

\section{Excerpt 1}

Tiếng Anh ngoài đời khác với tiếng Anh cô được dạy hồi cao đẳng lắm con! Hồi đó cô toàn họ tiếng Anh formal với văn phạm. Ở đây cô phải ra ngoài làm việc, phải tiếp xúc với tiếng Anh thông dụng hàng ngày. Cô phải tư học nhiều tù̀ (và) thành ngũu mói, riết rồi cũng quen.
[Real-life English is very different from what I was taught in college. I used to mainly study formal English and grammar. Here I have to go to work. I have to expose myself to English used in daily life.

I had to teach myself lots of new terms and slangs. I am used to them now.]

Apart from her initial hardships, another major reason that she deemed as a disadvantage to her target language development was the high ethnic concentration of Vietnamese immigrants in San Jose, as depicted in the following quote:

\section{Excerpt 2}

Cô đi ra đuờng ở đâu cũng nghe tiếng Việt: ở khu dân cu nhà cô ở, trong chợ, chố làm, rồi thậm chí trên (truyền thông) báo đài nữa! Nó tiện thật, nhưng mà cũng là một bất lợi. Con ở Mỹ, con PHẢI nói tiếng Anh chút! (Con) phải nói tiếng Anh mới làm việc với tụi Mỹ đurợc.
[I heard Vietnamese wherever I went to: the residential area where I lived, the supermarkets, the workplace, and even on multimedia!

It is truly convenient, but it is also a disadvantage.

You live in the United States. You MUST speak English!

(You) have to speak English to work with the Americans.]

As can be inferred, Phi implies it is pointless taking comfort in a closed Vietnamese enclave and speaking the mother tongue exclusively. She extends her language ideology to a larger context: the United States, in which everyone is supposed to have a good command of English, the mainstream language ("You live in the United States You MUST speak English!"). From her perspective, English can be regarded as a tool of communication among people of different linguistic backgrounds, in both local and global contexts. In addition, the target language is directly related to a discourse of immersion into the mainstream job market ("work with the Americans").

In one of her studies on language and transnational identity, Schneider (2014) points out English is not only associated with capitalist-competitive discourse, but it also reflects a progressive ideology towards new cosmopolitanism, in which nationalism is embedded within transnationalism and people in a transnational community share a universal language. Therefore, Phi's desire to become proficient in English, the mainstream language in her new homeland, not only expresses her belief the language would eventually grant her the access to employment, or a wider range of material and symbolic resources (Norton, 2013), but it also foregrounds an ideological shift from a localized space to a trans-localized one (from Vietnamese to English). However, Phi does not consider speaking her native language in the local community as 
illegitimate nor as a regression because she thinks of it as "truly convenient." Her words imply the immigrant community should transgress its locality and embrace the major element of the mainstream culture, the English language, as a way to go forward in the new land. Phi then shares her experiences in acquiring the new language:

\section{Excerpt 3}

Cô cố gắng giao tiếp với người bản xứ ở chố

làm hay ớ mấy chơ Mỹ.

Cô nghe đài tiếng Anh trên TV.

Hai đứa con cô cũng giúp cô với chú Binh hoc thêm (tiếng Anh).

Có tụi nó cô đõ̃ lắm, nhiều khi tụi nó giúp cô dịch thu hay là đi làm chúng tù chẳng hạn. Nhưng mà tụi cô không có thời gian đọc thêm báo hay sách tiếng Anh.

\author{
[I tried to communicate with native speakers \\ at work or at American supermarkets. \\ I listened to the news on TV. \\ My two sons have also helped me and Binh \\ to learn more (English). \\ They have been a big help. For example, \\ they assist me to translate mails or obtain \\ legal documents. \\ But we don't really have time to read \\ newspapers and books in English.]
}

At this point, Phi's language practices can be related to the theory of cognitive apprenticeship developed by Brown, Collins and Duguid (1989), based on Vygotsky's theory of social development (1978). According to Brown et al., the process of acquiring new concepts is via cognitive apprenticeship, which means learning occurs when learners participate in authentic activities. For example, when language learners are motivated to learn a new language, they usually seek to be actively engaged in listening, speaking, reading and writing the language. They therefore need help from people who have already mastered the language. In other words, they become apprentices of expert language users, who are mostly native speakers. Thus, learning could be seen as an acculturation process and knowledge can be best achieved by becoming an apprentice member within the culture. Also, Street (2007, 2009) and Lam and Warriner (2012) emphasize language and literacy practices shape and are shaped by how migrant learners position themselves in various social fields within and across national boundaries. In this case, Phi has been acquiring English by turning herself into an apprentice within an English-speaking environment and the target culture ("communicate with native speakers"; "listen to the news on TV").

On the other hand, her two sons who arrived in the States at a very young age (7 and 2) picked up the new language rapidly and soon obtained the native proficiency. As described by Phi, they adopt the role of being a translator and an intermediary between their parents and the target society ("translating mails or obtain legal documents"). Assuming the roles as language brokers and knowledge mediators, the second-generation migrant children tend to enhance literacy practices within the household through their bi-literacy, bilingual, and bicultural repertoires, thereby helping their parents mediate multidimensional cross-border practices and acculturate successfully into the mainstream culture (Lam \& Warriner, 2012; Orellana, 2009). Nonetheless, according to Phi, printed texts do not count as a means of practicing language for her and her husband. Instead, their trans-border literacy development transpires under other forms such as social engagement, media, and intergenerational involvement, which in turn contribute to the multiplex trait of transnationalism.

During my stay in Wichita, I was often taken aback by Phi's sons' Vietnamese proficiency. Not only can they speak, read, and write their homeland language fluently, but it is also more interesting to note that when conversing with me, they barely resort to code-switching nor code- 
mixing. When inquired about how she had managed to preserve her children's mother tongue and traditions, Phi elaborated:

\section{Excerpt 4}

(Dù) tụi nó nói tiếng Anh với nhau, nhưng cô với chú $B$ bắt tụi nó phải nói tiếng Việt với ba mẹ hay họ hàng.

Cô còn dạy tụi nó đọc (tiếng Việt) mỗi khi đi chơ hay ăn nhà hàng Việt. Mồi lần về Việt Nam cô còn dạy tụi nó nhiều hơn.

\section{Cô nghĩ biết hai ngôn ngũ là lợi thế lớn cho tui nhỏ.}

Tưi nó có thể làm việc ở bên đây (Mỹ) L $\tilde{A} N$ bên bển (Việt Nam) trong tuong lai.
[(Though) they speak English to each other, I and B make them speak Vietnamese to their parents or cousins. I also teach them how to read (Vietnamese) while shopping or dining in Vietnamese markets and restaurants. Whenever we go back to Vietnam, I even teach them more.

I think knowing two languages is a huge advantage for them.

They can work either here (the United States) OR there (Vietnam) in the future.]

This excerpt suggests how Phi and her husband's ideological influences have on her children's bi-literacy development and language maintenance in the family. It is also an illustration of how diasporic communities use available and growing linguistic and cultural resources originated from their transnational spaces ("Vietnamese markets and restaurants") to create symbolic ethnic connections cross-borderly and thus strengthen intergenerational relationships. Lam and Warriner (2012) asserts:

Narratives and other discourse practices in the family allow parents to maintain cultural ties while providing their children access to and participation in cross-cultural and linguistic borderland spaces (Lam \& Warriner, 2012, p. 199).

Furthermore, as discussed, Phi considers Vietnamese neither as a backward trend nor as an impediment to her children's literacy and language development. On the contrary, the minority language in this case is deemed as a valuable resource for the second generation "huge advantage"). Plurilingualism and cultural hybridity, in this case, are treated not only as a means to maintaining intergenerational and transnational ties, but also as a marketable commodity and metropolitan membership in the current globalized economy ("work either here or there"). As another significant way to sustain cross-border connections, she continues to share:

\section{Excerpt 5}

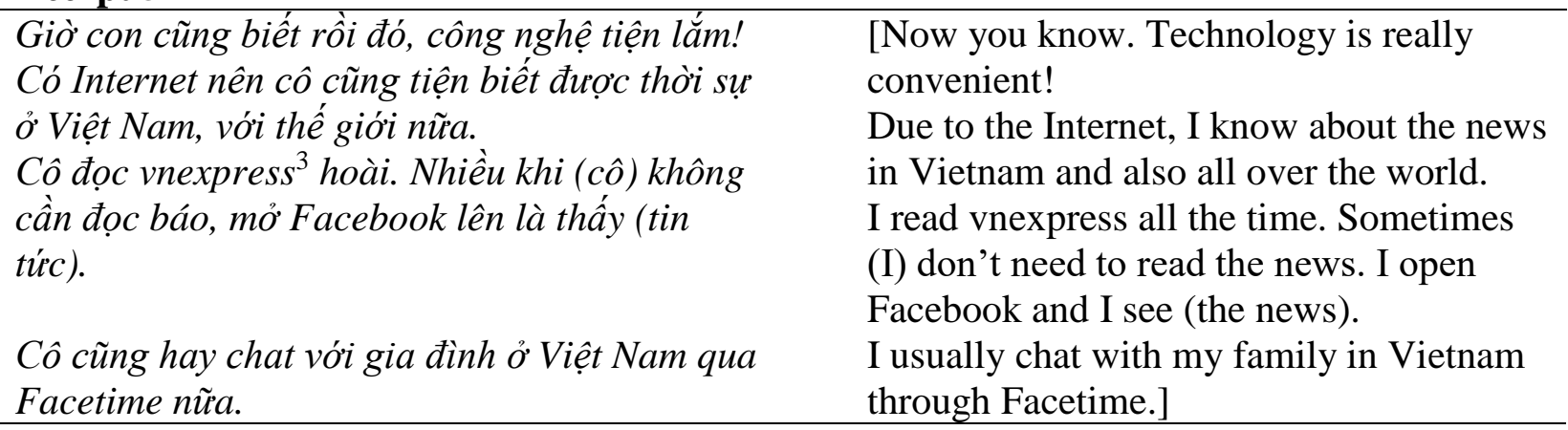


As can be inferred, Phi adopts technology and utilizes it in a binational context to communicate with people across borders and keep track of events in her homeland ("I know about the news in Vietnam and also all over the world"; "chat with my family in Vietnam through Facetime"). Technological progress has thus rendered national borders more and more porous. In this sense, technology is no longer a supplemental and neutral tool and has become an indispensable part of literacy practices, especially when it comes to transnational practices among migrant families. In other words, the rapid evolution of this new means of literacy enables "new forms of discourse, new forms of authorship, and new ways to create and participate in communities" (Kern 2006, p. 183). To be more specific, I observed that Phi sometimes participated in some well-known e-forums for ladies in Vietnam, which involve a diverse body of Vietnamese contributors worldwide, many of whom are expatriates, and they all make comments or share their experiences in their mother tongue. Phi is also an active user of Facebook: She does not only use Facebook to keep track of the news ("I open Facebook and I see the new"), but she has also shared a number of articles, videos, and images, either from Vietnam or from exotic sources, which she finds meaningful for her family, cousins, and friends as a means to maintaining transnational connection.

The modern migrant learners, from this perspective, have a tendency to optimally draw upon their inter-cultural, cross-border schemata and repertoires, though perhaps limited, to make efforts in engaging themselves in constructing and reconstructing the world knowledge; the transcultural development is thus meaningful and dramatically promoted. Taking poststructuralism into regard, the virtual community has provided Phi as well as other migrant learners a new space to "embrace and explore their transnational and transcultural identities" (Yi, 2009, p. 117). Also, as a supplement to the technological turn in identity and new literacy studies (Black, 2008; Darvin \& Norton, 2014; Norton, 2013; Thorne, Sauro \& Smith, 2015), technology and media landscape brings about a third space that helps learners renegotiate their identities and claim their newfound power positions. Phi's adoption of the third space serves as a tool to maintain social relationships with the homeland as well as other across-diaspora affiliations, thereby reinforcing her original sense of self and mobilizing collective ethnic identity. Technology, therefore, is of social, symbolic, and emotional significance in the lives of immigrants.

\section{Redefining the "American Dream"}

Apart from the reunification with her family-in-law, another main reason Phi and her husband chose to move to America was the strong belief that the U.S. education system would be of great benefit for their children. Phi's family left Vietnam with little knowledge of the sociocultural settings of the new land. Though originating as middle-school teachers, Phi and her husband had to resort to manual labor to make ends meet. The couple had undergone a wide range of low-paid jobs in San Jose before the global economic crisis in 2008 rendered them unemployed for about a year before moving to Wichita.

In the process of resettling in a new country, first-generation immigrants like Phi and Binh have to reproduce and reconstitute their dispositions through countless social, political and institutional forces at play (Navarro, 2006). In other words, they have to rearrange, expand, and renegotiate their perspectives on the world regarding various socio-historical, socio-economic backgrounds, power positions, cultural relationships, etc., as indicated in Phi's following recounts of her experience: 


\section{Excerpt 6}

\begin{tabular}{|c|c|}
\hline Hồi lúc mới qua (tụi cô) khổ lắm! & $\begin{array}{l}\text { [When we first came over here, it was } \\
\text { extremely difficult (for us)! }\end{array}$ \\
\hline $\begin{array}{l}\text { Chú Binh phải đè nén sự tụ tôn (và) sĩ diện của } \\
\text { ông. }\end{array}$ & $\begin{array}{l}\text { Binh had to compress his pride (and) self- } \\
\text { esteem. }\end{array}$ \\
\hline $\begin{array}{l}\text { Con cunng biết chú Binh là con tướng với còn } \\
\text { là giáo viên có tiếng ở Sài Gòn nữa. }\end{array}$ & $\begin{array}{l}\text { You know that he used to be a general's son } \\
\text { and a well-known teacher back in Saigon. }\end{array}$ \\
\hline Chú Binh lúc mói qua đòi về hoài! & He mentioned going back all the time! \\
\hline Cô đôi lúc cuñng vậy. & Sometimes I did the same thing. \\
\hline $\begin{array}{l}\text { Nhung mà tụi cô phải chịu khó vì tuoong lai của } \\
\text { tui nhỏ. }\end{array}$ & $\begin{array}{l}\text { But we had to endure because of the kids' } \\
\text { future.] }\end{array}$ \\
\hline
\end{tabular}

Bourdieu (1984) defines habitus as a set of dispositions that are both shaped by past events and structures, and that incline us to act in certain ways to conform to the social norms of the society we are living in, through which we define ourselves and through which others identify us. Navarro (2006) articulates habitus, as a product of social construction, leads to patterns that are not only enduring and transferable from one context to another, but also may change across time and space. Bourdieu (1980) also takes into account the tensions and contradictions that are likely to emerge when people encounter estranged and different contexts. In this case, Phi and her husband, who used to work as teachers, a relatively noble profession in their home country, had to "compress" their "pride" to do manual work to make a living. Since they set foot onto the new land, they have been exposed to a new network of multi-stranded relationships and discourses. Their power position shaped by the past incidents ("teacher" and "general's son") is applicable and transferable within the household and local/trans-local settings: Many of their acquaintances still call them "thầy" and "cô"-_Vietnamese formal terms for "male teacher" and "female teacher" respectively as a way to express respect towards their status in the past. However, their habitus, or social self-positioning and taken-for-granted assumptions, have been adapted into novel forms while transgressing the locality to transpire in a larger context (see Figure 1).

Figure 1. Old habitus and adapted habitus.

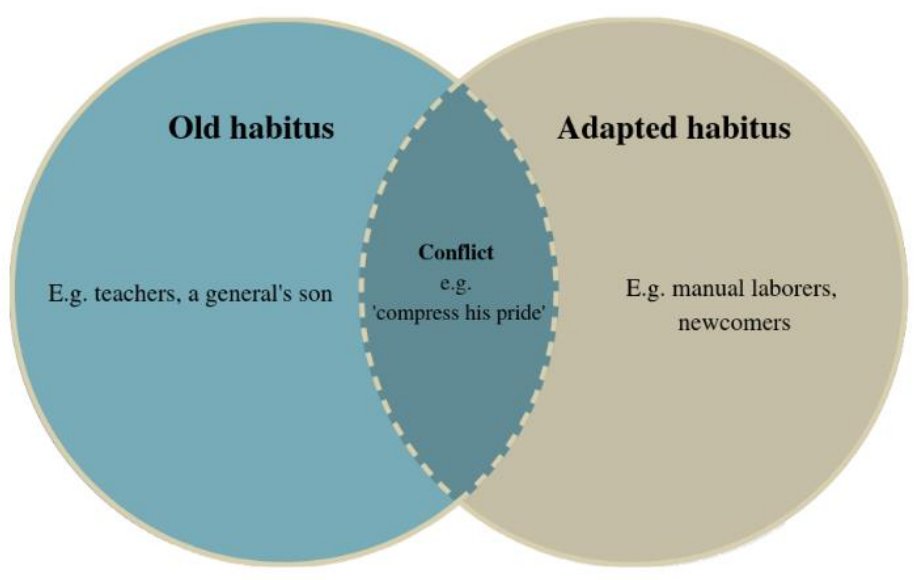

Immigrants, therefore, tend to adopt new identity constructs via various life experiences and situations from distinguished points of view of their native societies, which correlates with 
Norton's definition of identity construction as "issues of power distribution" and "continuous site of struggle" among migrant learners (Norton, 2013). It is also these multiple sets of new social norms that guide and reshape migrants' behaviors and practices across local and trans-local spaces, so that they can impose the recognition of themselves upon the majority culture, thereby once again shifting their power relations. Phi and Binh's narratives are representative of unceasing struggling for power: After having lived off government subsidies in the 2008 financial crisis period, Phi's family decided to relocate to Wichita, Kansas. Speaking of the reasons, Phi explains:

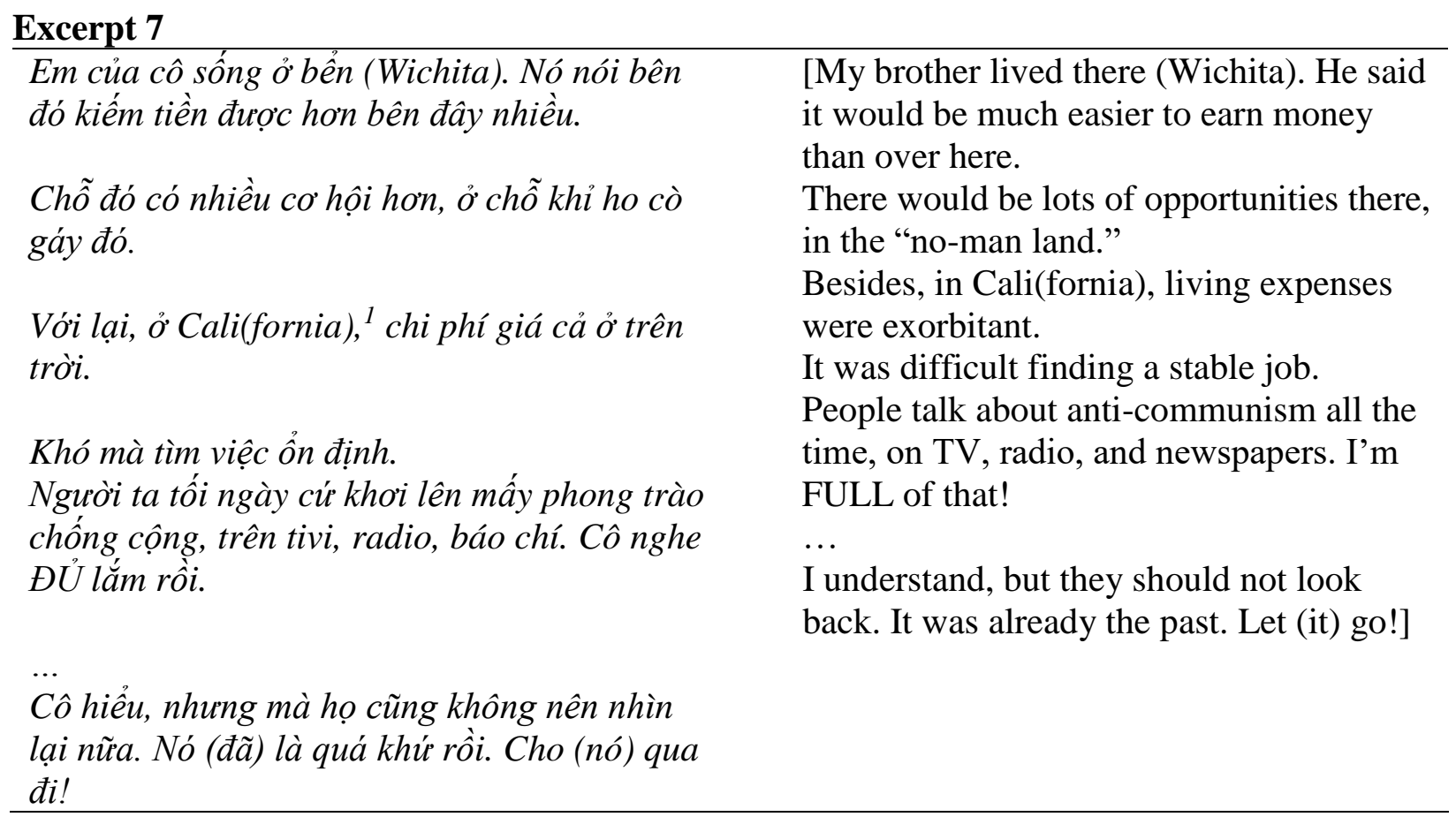

As mentioned, the fall of Southern Vietnam's government to the communist regime has triggered the Vietnamese migration to the United States since the 1970s. The Vietnamese diaspora began to come together to form a new immigrant community, and its culture of nostalgia thrived upon tragedy and trauma has been what defines the communal ethos. As Lam (2004) puts it, "To be a fully part of this community, members mourn, protest, and, on occasion, gather en masse to demand a communist-free homeland" (Lam, 2004, p. 34).

As an addition to Lam's description, Phi mentions the prevalence of anti-communist propagandas all over the media and it permeates the Vietnamese enclaves across California. This imagined nationalist stance, in this respect, contributes to forming a segregation between the Vietnamese diaspora and people from the homeland. Furthermore, discourses of anti-communism and nostalgia have constructed a new critical and transnational perspective that informs a majority of Vietnamese Americans and immigrants' construction of identity and other socio-culturalpolitical practices. For instance, in elaborating on Vietnamese transnational practices, Lieu (2011) asserts:

The American Dream for Vietnamese refugees and immigrants was generated and powered by nostalgia and a stake in both the sameness and the repetition of nostalgic experiences as 
well as the novelty of a cultural identity invested in consumption and commodity capitalism (Lieu, 2011, p. 132).

Lieu's statement suggests an essentialist standing, in which she argues nostalgia necessarily plays a major role in the Vietnamese communities' cultural retention and maintenance, which "supports an ideological stance against communism" (Lieu, 2011, p. 132). She characterizes the diasporic values without conducting multi-sited ethnography, which follows the trajectories of people as they move across physical spaces (Marcus, 1998). This approach, as Schneider (2014) points out, may reconstruct the pre-existing national discourse, thus dismantling essentialism. Phi's words, therefore, act as a counterargument to the Vietnamese Americans' collective anticommunism culture, which is predominant in a number of studies on the population (Anguilar-San Juan, 2009; Dang, 2005; Le, 2009; Lieu, 2011; Vu, 2006). This finding is also consistent with a growing body of scholarly works on Vietnamese Americans that take an ideological stance against anti-communism (Espiritu, 2005, 2006; Thu-Huong, 2005; Vo, 2003). From a person immersed in anti-communism discourse, Phi construed it as a backward mindset ("they should not look back") and therefore chose to move away from it to seek a more upward mobility ("lots of opportunities"). This ideological difference also reflects the distinction between the Old Enclave and the New Enclave. The following ethnographic data sheds more light on Phi's trajectory towards securing a middle-class identity:

Phi's family were relocating to another house during my stay with them. After moving to Wichita, they seemed much better off with a new spacious four-bedroom house and two personal vehicles. Her husband's perspective on life have changed considerably. He seems satisfied with his current life, despite his hard work as a manual worker. And they take pride in their children, who have obtained distinct academic achievements in recent years.

In this excerpt below, radical changes concerning her perceptions of the American Dream can be spotted:

\section{Excerpt 8}

\begin{tabular}{|c|c|}
\hline $\begin{array}{l}\text { Có cơ hội là cô NHÀO vô làm overtime liền } \\
\text { để kiếm thêm tiền (để) trả góp căn nhà mới. }\end{array}$ & $\begin{array}{l}\text { [I JUMP at every chance I have to work } \\
\text { overtime to make extra money (to) pay off } \\
\text { the mortgage for our new house. }\end{array}$ \\
\hline Cô được trả double vào cuối tuần nũa. & I also get paid double on the weekend. \\
\hline Nhan nó sắp lên đại học rồi. Tụi cô đang & Nhan is going to college soon. We are \\
\hline kiếm cho nó chiếc xe cũ. & looking for a used car for him. \\
\hline$\ldots$ & .. \\
\hline Cô cũng muốn mở business riêng. & I also want to start my own business. \\
\hline Cô thấy ở Kansas này nhiều co hội quá! & I see vast opportunities here in Kansas! \\
\hline Không có nhiều người Châu Á ở đây. & There are not a lot of Asians here. \\
\hline Ơ đây người ta có co hội làm giàu nhu nhau. & Here people have equal chances to get \\
\hline Cô muốn lắm, nhung mà ... cô sợ tại cô chura & rich. \\
\hline làm kinh doanh bao giờ. & $\begin{array}{l}\text { I want it, but ... I'm afraid as I haven't } \\
\text { done business before.] }\end{array}$ \\
\hline
\end{tabular}


As can be seen, stories of struggling with life gradually have given way to "overtime," "mortgage," "car" and "equal chances," which Lam (2004) describes as the language of the American Dream. Phi, in this respect, has been able to overcome the collective culture built on nostalgia and anti-communism discourse, which is ubiquitous in the Old Enclave, to reach the newfound discursive realms of liberalism and neo-liberalism, in which people have equal opportunities to freely practice economic privatization and thus climb to higher social hierarchy. In other words, she has overstepped the provincial ideologies to merge into the American narratives of moving forward, progression, egalitarianism, and democracy. Her mention of the scarce presence of Asian populace in the area also reflects her re-conceptualization of the new homeland: bimodal racial discourse, which is comprised of mostly African- and CaucasianAmericans, has been extended to a multi-polar one, through which Phi does not only imply her recognition of Asian Americans ("There are not a lot of Asians here"), but she also means to include multiple-race dialogues all across the country. The American Dream, as Phi defines, no longer regurgitates the historical tensions between the diaspora and the homeland; instead, it has taken the new shape of liberalism, neo-liberalism, and cosmopolitanism in the New Enclave.

\section{Conclusion and Ways Forward for Future Studies}

All things regarded, this study is focused on the transnational language learning experiences, literacy practices, and changed perceptions of a Vietnamese immigrant family who made the transition from the Old Enclave, the original Vietnamese diaspora built upon anti-communism, to the New Enclave, the recent Vietnamese diaspora built upon neo-liberalism and new cosmopolitanism. Via the ethnographic data and discourse analysis, I believe this paper has been able to give proper answers to the research questions raised above, as well as to demonstrate immigrants' complex and dynamic engagement in diverse social fields that span within and across national boundaries, and the role of language and literacy practices in re-establishing their relations in those fields. Phi's rich and informative narratives are representative of the intersection of local and global, the ideological shift across time and space, the constant struggling for power positions, and the reconstruction of identities among many other migrant communities in the United States.

Throughout this paper, I explored various issues regarding contemporary contexts of migration and transnationalism. In doing so, I have also come up with some ways forward for future directions in the field. Firstly, though there is a wide range of studies that focus on literacy and language learning practices among immigrant families, I concur with Lam \& Warriner (2012) that there has been little work with regard to other transnational social fields, for example, work, education, politics, etc. This paper, for example, should have extended its scope on how Phi and her husband have developed their transnational habitus (Guarnizo, 1997) through their lived experiences across new values and norms in the workplace as well as in various other social structures and fields such as civic and political involvement. Secondly, Phi's children's involvement suggests future studies should give more space for the intergenerational process, which plays a significant role in reformulating literacy and language practices in migrant families. This focus, on the other hand, implies a further direction which spans the field of comparative studies, in which comparing and contextualizing literacy practices between native- and foreignborn youths "within particular social and political conditions of migration would contribute to more nuanced understandings of the literacy learning and development of youths in transnational contexts" (Lam \& Warriner, 2012, p. 211). This holds particularly true in the setting of Vietnamese migration, where there has been a long-standing ideological segregation between the Vietnamese 
Americans from the Old Enclave and the Vietnamese from the homeland. The suggested methodological approach, therefore, may subvert the divisive discourse between the two communities and "lead to the compassion and humanization of others" (Gilroy, 2005, p. 67).

What is more, I strongly call for an emphasis on the technological turn among migrant learners' transnational literacy and language practices. As a present-day social space as well as an immense semiotic and inter-cultural repertoire, technology-mediated practices have by far presented enormous potential for gaining deep insights into how multiple identities are implemented, negotiated, and reconstituted within and across local networks and national spaces. Technology, in this sense, is not only a tool for empowering and reinforcing identities, but it is also the "transnational voice that migrant learners can share their distinct histories and unfolded stories, and pursue their imagined futures" (Darvin \& Norton, 2014).

Last but not least, globalization, along with its nature which is constantly in flux, has expanded the meaning of the term transnationalism, which, in this sense, is not only restrained to matters of migration, but it also encompasses other cross-border movements. In particular, little research on trans-border practices has been conducted on the emerging segment of populations who are working or studying overseas, or expatriates. Their narratives concerning how they renegotiate themselves in an age of open systems and porous borders turns themselves into the primary subjects in this increasingly globalized world (Lam, 2004). Such exploration may inspire further studies on post-modernism, which raises skeptical questions on modern categories and boundaries such as nation-states, classes, gender, literacy, language, politics, mobility, etc., thus deconstructing and re-conceptualizing the foundations of our current societies (Beck et al, 2003).

\section{Notes}

1. I hereby argue that there exists a dichotomy in political ideologies among Vietnamese Americans, in which (a) the Old Enclave thrive upon anti-communism and nostalgia and (b) the New Enclave is built upon neo-liberalism and new cosmopolitanism-a form of nationalism situated within transnationalism and pluralism. This will be later elaborated in this paper.

2. All the names used in this paper are pseudonyms.

3. A popular Vietnamese e-newspapers.

4. Vietnamese tend to refer to California as Cali.

\section{References}

Aguilar-San Juan, K. (2009). Little Saigons: Staying Vietnamese in America. Minneapolis, MN: University of Minnesota Press.

Appadurai, A. (1996). Sovereignty without territoriality: Notes for a postnational geography. In S. M. Lawrence-Zuniga, The anthropology of space and place: Locating culture (pp. 337349). Malden, MA: Blackwell.

Barkhuizen, G. P. (2008). A narrative approach to exploring context in language teaching. English Language Teaching Journal, 231-239.

Basch, L. G. (1994). Nations unbound: Transnational projects, postcolonial predicaments and deterritorialized nation-states. New York, NY: Routledge. 
Baynham, M., \& Prinsloo, M. (2009). The future of literacy studies. London, UK: Palgrave MacMillan.

Beck, U., Bonss, W., \& Lau, C. (2003). The theory of reflexive modernization: Problematic hypotheses. Theory, Culture, and Society, 20, 1-33.

Benitez, J. L. (2006). Transnational dimensions of the digital divide among Salvadoran immigrants in the Washington DC metropolitan area. Global Networks, 6(2), 181-199.

Black, W. R. (2008). Just don't call them cartoons: The new literacy spaces of anime, manga, and fanfiction. Handbook of research on new literacies, 583-610.

Block, D. (2006). Multilingual identities in a global city: London stories. London, UK: Palgrave.

Block, D. (2007). Second language identities. New York, NY: Continuum.

Bourdieu, P. (1984). Distinction: A social critique of the judgement of taste. London, UK: Routledge.

Bourdieu, P. (1992). The logic of practice. Palo Alto, CA: Stanford University Press.

Brown, S. J., Collins, A., \& Duguid, P. (1989). Situated cognition and the culture of learning. Educational Researcher, 18(1), 32-42.

Corbin, J., \& Strauss, A. (2008). Basics of qualitative research. Los Angeles, CA: Sage.

Cruickshank, K. (2006). Teenagers, literacy and school: Researching in multilingual contexts. New York, NY: Routledge.

Dang, T. V. (2005). The cultural work of anticommunism in the San Diego Vietnamese American community. Amerasia Journal, 31(2), 65-86.

Darvin, R., \& Norton, B. (2014). Social class, identity, and migrant students. Journal of Language, Identity, and Education, 13(2), 111-117.

Early, M., \& Norton, B. (2012). Language learner stories and imagined identities. Narrative Inquiry, 22(1), 194-201.

El-Haj, A. R. (2007). "I was born here, but my home, it's not here": Educating for democratic citizenship in an era of transnational migration and global conflict. Harvard Educational Review, 77(3), 285-316.

Espiritu, Y. L. (2005). Thirty years after war: The endings that are not over. Amerasia Journal, 31(2), 13-23.

Espiritu, Y. L. (2006). "We-win-even-when-we-lose" syndrome: United States press coverage of the twenty-fifth anniversary of the "fall of Saigon." American Quarterly, 58(2), 329-352.

Geertz, C. (1977). The interpretation of cultures. New York, NY: Basic Books.

Gilroy, P. (2005). After empire: Multiculture or postcolonial melancholia. New York, NY: Columbia University Press.

Gobo, G. (2008). Doing ethnography. London, UK: Sage.

Guarnizo, L. E. (1997). The emergence of a transnational social formation and the mirage of return migration among Dominican transmigrants. Identities, 4(2), 281-322.

Kern, R. G. (2006). Perspectives on technology in learning and teaching languages. TESOL Quarterly, 40(1), 183-210.

Lam, A. (2005). Perfume Dreams: Reflections on the Vietnamese Diaspora. San Francisco, CA: Heyday Books.

Lam, E. S., \& Warriner, S. D. (2012). Transnationalism and literacy: Investigating the mobility of people, languages, texts, and practices in contexts of migration. Reading Research Quarterly, 47(2), 191-215. 
Le, C. N. (2009). "Better dead than red": Anti-communist politics among Vietnamese Americans. In I. Zake (Ed.), Anti-communist minorities in the US: The political activism of ethnic refugees (pp. 189-210). New York, NY: Palgrave-MacMillan Publishing.

Lieu, N. T. (2011). The American dream in Vietnamese. Minnesota, MN: University of Minnesota Press.

Marcus, G. E. (1998). Ethnography through thick and thin. Princeton, NJ: Princeton University Press.

Merriam, S. (1998). Qualitative research and case study applications in education: Revised and expanded from case study research in education. San Francisco, CA: Jossey-Bass.

Miller, J. (2003). Audible difference: ESL and social identity in schools. Clevedon, UK: Multilingual Matters.

Moje, E. B., \& Luke, A. (2009). Literacy and identity: Examining the metaphors in history and contemporary research. Reading Research Quarterly, 44(4), 415-437.

Navarro, Z. (2006). In search of cultural interpretation of power. Institute of Development Studies Bulletin, 37(6), 11-22.

Norton, B. (2000). Identity and language learning: Gender, ethnicity, and educational change. London, UK: Longman.

Norton, B. (2013). Identity and language learning: Extending the conversation. Bristol, UK: Multilingual Matters.

Orellana, M. (2009). Translating childhood: Immigrant youth, language, and culture. New Brunswick, NJ: Rutgers University Press.

Panagakos, A. N., \& Horst, H. A. (2006). Return to Cyberia: Technology and the social worlds of transnational migrants. Global Networks, 6(2), 109-124.

Rubinstein-Avila, E. (2007). From the Dominican Republic to Drew High: What counts as literacy for Yanira Lara. Reading Research Quarterly, 42(4), 568-587.

Sanchez, P., \& Salazar, M. (2012). Transnational computer use in urban Latino immigrant communities: Implications for schooling. Urban Education, 47(1), 90-116.

Schiller, N. G., Basch, L., \& Blanc-Szanton, C. (1992). Towards a definition of transnationalism. Annals of the New York Academy of Science, 645, ix-xiv.

Schiller, N. G., Basch, L., \& Blanc-Szanton, C. (1992). Towards a definition of transnationalism. Annals of the New York Academy of Sciences, 645(1), 9-14.

Schneider, B. (2014). Salsa, language and transnationalism. Bristol, UK: Multilingual Matters.

Smith, M. P. (2003). Transnationalism, the state, and the extraterritorial citizen. Politics \& Society, 31(4), 467-532.

Street, B. V. (2003). What's "new" in new literacies studies? Critical approaches to literacy in theory and practice. Current Issues in Comparative Education, 5(2), 77-91.

Street, B. V. (2007). Foreword. In C. Lewis, P. E. Enciso, \& E. B. Moje (Eds.), Reframing sociocultural research on literacy: Identity, agency, and power (pp. vii-x). Mahwah, NJ: Erlbaum.

Street, B. V. (2009). The future of social literacies. In M. Baynham, \& M. Prinsloo (Eds.), The future of literacy studies (pp. 21-37). London, UK: Palgrave MacMillan.

Suarez-Orozco, M. (2001). Globalization, immigration, and education: The research agenda. Harvard Educational Review, 71(3), 345-365.

Thorne, L. S., Sauro, S., \& Smith, B. (2015). Technologies, identities, and expressive activity. Annual Review of Applied Linguistics, 35, 215-233. 
Thu Huong, N. V. (2005). Forking paths: How shall we mourn the dead? Amerasia Journal, 31(2), $157-175$.

Vo, L. (2003). Vietnamese American trajectories: Dimensions of diaspora. Amerasia Journal, 29(1), 9-18.

Vo, T. L. (2000). The Vietnamese American experience: From dispersion to the development of post-refugee communities. In J. Y. Song (Ed.), Asian American Studies: A reader (pp. 290305). New Jersey, NJ: Rutgers University Press.

Vu, R. (2006). From the ashes of the Cold War: Constructing a Southern Vietnamese community and identity in Houston. The Houston Review, 3(1), 27-66.

Vygotsky, L. (1978). Mind and society. Cambridge, MA: Harvard University Press.

Warriner, D. S. (2007). Transnational literacies: Immigration, language, and identity. Linguistics and Education, 18, 201-214.

Wilding, R. (2006). "Virtual" intimacies? Families communicating across transnational contexts. Global Networks, 6(2), 125-142.

Yi, Y. (2009). Adolescent literacy and identity construction among 1.5 generation students from a transnational perspective. Journal of Asian Pacific Communication, 19(10), 100-129.

Appendix: Symbols used in transcription.

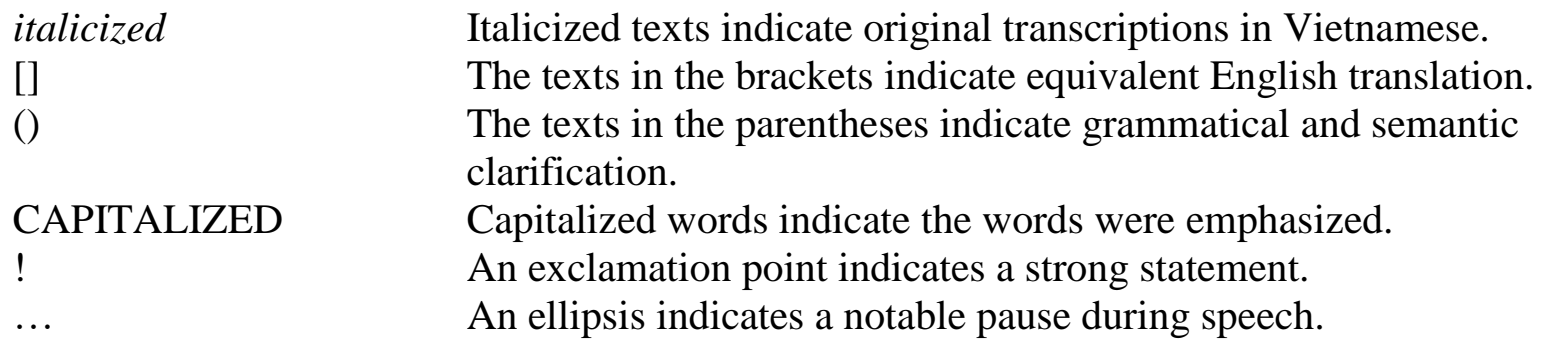

\begin{abstract}
About the Author

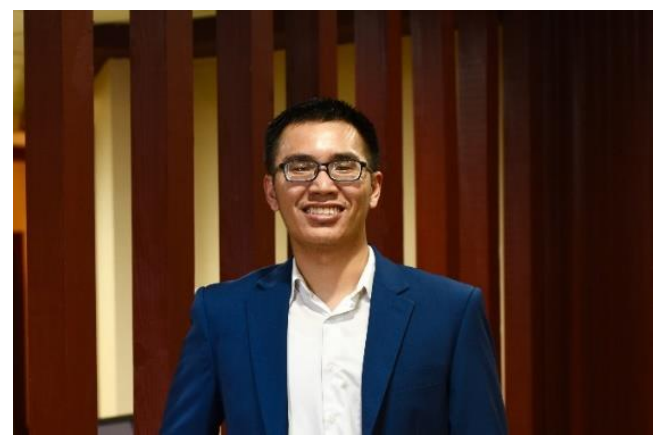

Nguyen Dao, is a Ph.D. student in Culture, Literacy, and Language at the University of Texas at San Antonio. Before moving to San Antonio, Nguyen used to work as an ESL teacher in Vietnam. Then he earned his M.Ed. in Curriculum \& Instruction from the University of Houston and worked in Houston for two years as an academic program coordinator. His research interests include language learning, literacy practices, and identity among Vietnamese- and Asian-Americans. He is now working as a graduate research assistant and as the academic coordinator of the Texas Language Education Research (TexLER) committee. He is also a member of the Doctoral Student Editorial Review Board for Journal of Southeast Asian American Education and Advancement (JSAAEA).
\end{abstract}




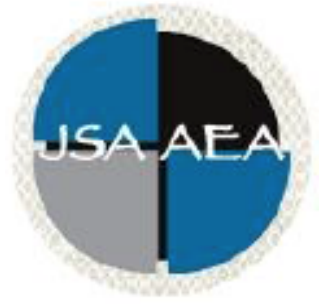

Vol.14 Iss.1 (2019)

\title{
Journal of Southeast Asian American Education and Advancement
}

\author{
www.JSAAEA.org
}

\section{Editor}

Dr. Wayne E. Wright

Purdue University

Associate Editors

Dr. Chhany Sak-Humphry

University of Hawaii at Manoa

Dr. Phitsamay Sychitkokhong Uy

University of Massachusetts, Lowell

\author{
Book Review Editor \\ Dr. Vichet Chhuon \\ University of Minnesota \\ Creative Works Editor \\ Bryan Thao Worra \\ Lao Assistance Center \\ Journal Manager \\ Fang Gao \\ Purdue University
}

\section{Editorial Review Board}

Dr. Steve Arounsack

California State University, Stanislaus

Dr. Sovicheth Boun

Salem State University

Dr. Virak Chan

Purdue University
Dr. Carl L. Bankston III

Tulane University

Dr. Phala Chea

Lowell Public Schools

Dr. George Chigas

University of Massachusetts, Lowell 


\author{
Dr. Loan Dao \\ University of Massachusetts Boston \\ Dr. Changming Duan \\ University of Missouri-Kansas City \\ Dr. Sothy Eng \\ Lehigh University \\ Dr. Vincent K. Her \\ University of Wisconsin, Eau Claire \\ Dr. Peter Nien-Chu Kiang \\ University of Massachusetts, Boston \\ Dr. Kevin K. Kumashiro \\ University of Illinois, Chicago \\ Dr. Ha Lam \\ Independent Scholar \\ Dr. Jonathan H. X. Lee \\ San Francisco State University \\ Dr. Monirith Ly \\ Royal University of Phnom Penh \\ Dr. Bic Ngo \\ University of Minnesota \\ Dr. Leakhena Nou \\ California State University, Long Beach \\ Dr. Mark Pfeifer \\ SUNY Institute of Technology \\ Dr. Loan T. Phan \\ University of New Hampshire \\ Dr. Karen Quintiliani \\ California State University, Long Beach \\ Dr. Angela Reyes \\ Hunter College \\ The City University of New York \\ Dr. Fay Shin \\ California State University, Long Beach \\ Dr. Christine Su \\ College of San Mateo \\ Dr. Alisia Tran \\ Arizona State University \\ Dr. Khatharya Um \\ University of California, Berkeley \\ Dr. Kim Tran \\ University of California, Los Angeles, \\ Glendale Community College \\ Dr. Molly Wiebie \\ The University of Texas at Austin
}

Dr. Hien Duc Do

San Jose State University

Dr. Sophal Ear

Occidental College

Dr. Jeremy Hein

University of Wisconsin, Eau Claire

Dr. Nancy H. Hornberger

University of Pennsylvania

Dr. Peter Tan Keo

New York University

Dr. Yvonne Kwan

San Jose State University

Dr. Ravy Lao

California State University, Los Angeles

Dr. Stacey Lee

University of Wisconsin, Madison

Dr. Sue Needham

California State University, Dominguez Hills

Dr. Max Niedzwiecki

Daylight Consulting Group

Dr. Clara Park

California State University, Northridge

Dr. Giang Pham

University of Massachusetts Amherst

Dr. Malaphone Phommasa

University of Clifornia Santa Barbara

Dr. Kalyani Rai

University of Wisconsin-Milwaukee

Dr. Cathy J. Schlund-Vials

University of Connecticut, Storrs

Dr. Nancy J. Smith-Hefner

Boston University

Dr. Yer J. Thao

Portland State University

Dr. Monica M. Trieu

Purdue University

Dr. Silvy Un

Saint Paul Public Schools

Dr. Linda Trinh Vo

University of California, Irvine

Dr. Yang Sao Xiong

The University of Wisconsin-Madison

Dr. Zha Blong Xiong

University of Minnesota 


\section{Doctoral Student Editorial Review Board}

\author{
Linh Dang \\ University of Rochester \\ My-Lan Huynh \\ California State University East Bay \\ Hoa Nha Nguyen \\ Boston College \\ Thien-Huong Ninh \\ University of Southern California \\ Krissyvan Truong \\ Claremont Graduate University \\ Melissa Vang \\ San Diego State University \\ Claremont Graduate University \\ Nielsen Hul \\ Cornell University \\ Bao Diep \\ University of Minnesota
}

\author{
Annie BichLoan Duong \\ San Joaquin County Office of Education \\ Dung Minh Mao \\ University of Minnesota \\ Khoi Nguyen \\ George Mason University \\ Linda Marie Pheng \\ University of Wisconsin-Madison \\ Mai Vang \\ University of Massachusetts Boston \\ Soua Xiong \\ San Diego State University \\ Claremont Graduate University \\ Diana Chandara \\ University of Minnesota \\ Thong Vang \\ University of Minnesota
}

